\title{
On the Dispersal of Seeds by Wind.
}

\author{
BY
}

\author{
HENRY N. RIDLEY, F.L.S., \\ Director of the Botanic Gardens, Singapore.
}

- $\mathrm{HE}$ work of the wind as a means of seed-dispersal and of spore-dispersal 1 is one of the most important subjects in Geographical Botany. We cannot say that a conclusive opinion has yet been arrived at regarding it.' Thus writes Schimper in 'Plant Geography'(English Edition). 'A. deCandolle and Kerner estimate the efficiency at a very low figure in the case of seed plants.' This important subject having been always of some interest to me, I would make some suggestions and record some observations I have had opportunities of making from time to time in the tropics, as a contribution to the study of the question; and this the more readily as I have observed that most of the observations on the subject recorded have been made in cold climates, where the country is more open and less afforested than it is on the equator.

Seeds or fruits adopted for dispersal by wind may be put into three groups : (I) Winged fruits or seeds, such as those of most of the Dipterocarpeae and Bignoniaceae; (2) Plumed fruits or seed, e.g. Compositae and Apocynaceae ; (3) Powder-seed, fine and dustlike, as in Orchideae or Fern spores.

\section{WING-SEED.}

In the Malay Peninsula we have a considerable number of trees of great size and also of lofty climbers which have winged seeds or fruit, and which are disseminated from the parent tree by the aid of these wings. To what distance do these seeds or fruits travel, and what is the rate of progress in this way of the species over a given area?

I will first deal with the wing-fruited Dipterocarpeae, of which a number of species occur in the jungle in the Singapore Botanic Gardens and are fruiting at the present time (September). The weather is squally, with often violent storms of wind and rain of short duration. Prolonged violent wind is very rare in this country, but small cyclonic storms occasionally occur. Typhoons such as are characteristic of the Chinese sea are quite

[Annals of Botany, Vol. XIX. No. LXXV. July, I905.] 
unknown. The wind usually persists in one direction, according to the time of year; but at present, though from the south-east, it veers round occasionally to the west.

Shorea leprosula, Miq., is a very common tree in most parts of the peninsula, occupying a very large area and occurring also in Sumatra and Borneo. It attains a great height, 100 to 150 feet, with a straight tall stem and a big head of foliage. It usually fruits about once in five years, and then produces a vast amount of fruit. As in most of these trees, a very large proportion of the fruit is barren, and this falls first. Then after a time the ripe fruit falls. The fruit is about half an inch long, with three equal wings (modified calyx-lobes) $2 \frac{3}{4}$ inches long, half an inch broad, linear, oblong, blunt; when the fruit falls it rotates rapidly, descending with the ovary downwards.

It appears to have no other modification for dispersal, and is apparently not disseminated in any way by animals ; but the fruits of these Dipterocarpeae are often eaten apparently by rats, in which case the fallen fruits attacked by them are quite destroyed on the spot.

A big tree in the Botanic Gardens, 100 feet tall, stands in an open spot, but about 20 yards away on one side is the jungle, through which wide paths run, so that the plant has exceptional advantages for dispersing its seeds.

I surmise that the tree is about 100 years old, perhaps more. These Dipterocarpeae are of slow growth, and the Shoreas at least do not fruit till they are fully thirty years old, when they are about 30 feet tall. Fruits from small trees do not fly so far as those from large trees, as the surrounding foliage of the forests being much taller prevents their receiving the full force of the wind. I have been in high forests in a gale, when, though the wind was tearing through the upper branches of the trees 100 feet high and upwards, and throwing down large boughs, there was no wind below, where I was standing.

The furthest limit I have found the fruit from this Shorea was a single one 98 yards from the tree-base, on a grass plot. The greatest number fell within 20 yards of the tree, and continued abundant up to 40 yards. I saw none beyond this distance in the jungle; on paths and grass they naturally get drifted a little further after alighting, pushed along by wind, or the gardeners' brushing, or some such accident not possible in the forest. The distance may therefore be for purposes of estimation calculated at 100 yards at the outside, though practically it must be rare for them to go 50 yards.

The furthest young tree descended from this big Shorea leprosula is 40 yards away from the parent tree, and though many thousands of seeds must have been blown into the neighbouring jungle, there are only about a dozen young plants in the ncighbourhood. Fruits dropped from my 
verandah, I 7 feet high, where there was no wind, fell vertically for 5 or 6 feet before beginning to rotate, and lit within 6 feet of the place where they would have fallen had they had no wings.

If we assume that a tree flowers and fruits at 30 years of age and the fruits are disseminated to a distance of $I 00$ yards, that the furthest fruits always germinate and so continue in one direction, it will be seen that under such most favourable circumstances the species can only spread 300 yards in 100 years, and would take 58,666 years to migrate 100 miles. This seems an extraordinarily slow rate of migration, but I believe I have much overrated the rapidity. Occasional increases might occur, such as the falling of a seed on a log drifting down a stream, or into the stream itself; but there are very few or no streams in the hilly slopes of the peninsula which are strong enough to carry the seed. Again, excessively violent storms of wind might carry them further than usual, but such storms are nowadays at least very rare. I have seen these Dipterocarpeae in fruit during as violent wind storms as we ever have, and even then the fruits did not fly Ioo yards. Allowing for all these possibilities, it will be seen that in these calculations I have estimated the flight at 100 yards, whereas few fruit have been found more than 40 yards from the tree, nor have young trees of any age been found at a much greater distance. Further, in the progress of the species it has been assumed that the very furthest fruit in one direction have developed into trees, whereas it usually happens that bad seed drifts further than the heavier fertile seed, and it is also assumed that the wind always blows violently in the same direction when the tree is in fruit, which is not always the case; again, in the exceptional cases in which these fruits were found at upwards of Io0 yards from the tree, the tree was very much taller than the surrounding vegetation, and had a clearer line of flight than it would have had in the primaeval forest, where many trees would be on the same level, and their foliage would check the flight from the adjacent trees; and again, trees of thirty years of age being comparatively short would get much less of the wind than the taller century-old trees, and their fruit would certainly take a shorter flight.

The Malay Peninsula consists to a large extent of hilly country, the hills rising to a height of 7,000 feet, but Dipterocarpeae are not met with much above 2.500 feet altitude. The hills, and indeed the whole country where these plants occur, are densely wooded, and it might be suggested that the fruits would fly to greater distances down the hill slopes in heavy gales. This might be so; but it must be remembered that in its migrations a species would have to fly uphill quite as often as it flew down, and its progress uphill would be proportionately slower. Taking all these facts into consideration, it would not seem that I have under-estimated the time taken by a Dipterocarpous tree to migrate a hundred miles, but that on 
the contrary it is probably on an average nearly twice as long. If this is so it follows that the family must be of great antiquity, as must also be the forest-region which most of the species now occupy.

As it is impossible that the fruits of these trees can cross the sea in good enough condition to germinate, even if they ever reached the sea or could grow on the sea-shore when stranded, it follows that the whole area occupied by them must have been connected by dry land when they migrated, whether from Cambodia to the Philippines, or Borneo or Sumatra; but at what period this was we cannot even surmise.

Shorea macroptera, Dyer. A tree about 70 feet tall grows in a wood near the house. It is evidently an old tree, as it is partly hollow. It is a smaller species than $S$. leprosula, and fruits rather earlier; a tree planted in I 884 is now fruiting, though only about 30 feet tall. The furthest fallen fruit I can find is just 40 yards from the tree, and the only seedlings not further than 20 yards. This tree well overtops the rest of the surrounding wood, and is in a well-exposed position, so that it gets the full force of the wind.

The wood has grown up on ground evidently cleared at some period, with only a few of the original forest trees left, including the Shorea. The whole of the trees, as far as I can see, are those whose seed is regularly distributed by birds, bats and civet cats, together with stray fruit trees, planted, or seedlings from fruit grown or eaten near the house.

A nother tree about 30 feet tall in jungle had the greater part of its fruit lying just beneath it, and nearly all destroyed by mice; but I found a few seed about 30 yards away from it in the jungle.

Shorea gratissima, Dyer. A tall tree, about 80 feet high, growing in a wooded part of the gardens, fruits tolerably regularly more or less each year, but often dropping a year or two. The most distant fruits were found about 16 yards from the base of the tree. These fruits are five-winged, but three wings are larger than the other two. It flies less well than Shorea leprosula.

Shorea rigida, Brandis. A very large tree in the jungle, with trees as tall surrounding it. The fruits fall about 20 yards at the furthest, and young trees are to be seen about the same distance from the parent. Trees planted in another part of the gardens about twenty years ago are still quite small.

Anisoptera costata, Miq. Tree over 60 feet tall in jungle. It fruits more or less every year, but only in quantity once in five years. It flowered this year, but I could only find one fruit. The fruit is large, with broad wings and heavy; surrounded by jungle the greater part of the fruits fall within 6 yards of the trunk, and the furthest young trees I can find are within 15 yards of the parent tree.

The Dipterocarpeae, at least almost all the species with winged fruits, inhabit only dense forests far from streams by which the migration of the 
fruit might be hurried on; $D$. oblongifolius is the only exception I know. It lives on the banks of streams, and the fruits drift down, and I have even seen them in the sea, but dead. Yet several species range from the mouth of the peninsula to Banka and Borneo. Dryobalanops aromatica, Gaertn., occurs in three localities in the peninsula only, so far as is known, and is confined to small areas in those localities. They are at Rawang in Selangor, on the west of the peninsula ; Endau river, Johor, and Kwantan in Pahang in the east of the peninsula ; and it is also abundant in Borneo and the Philippines; so that to reach Rawang from Kwantan (about 1 Io miles, going in a straight line) under the most favourable circumstances it would take 58,300 years, and from Borneo ( 300 miles further) 266,710 years. This seems almost incredible, but it is improbable that the tree moved even as fast as this. Dipterocarpus grandifolius, Blanco, ranges from the peninsula to the Philippines, and if we assume that at the time of its migration the Philippines were connected by land with the peninsula, the shortest way the plant could go would occupy $1 \frac{1}{2}$ million years. The fruit of this tree, however, is much heavier than that of Shorea, and it is improbable that it would drift with the wind as far as Ioo yards. The whole area of the wing-fruited Dipterocarpeae extends from Burmah to the Philippine Islands. The most widely distributed seem to be-

Dryobalanops aromatica, Gaertn. Rawang, Malay Peninsula, to the Philippines.

Anisoptera glabra, Kurz. Yoma, Cambodia, and Cochin China to Singapore.

Anisoptera costata,-Korth. Singapore to South-east Borneo.

A. Curtisii, King. Penang to North-west Borneo.

Dipterocarpus Griffithii, Miq. Mergui, Andamans, to Pahang.

D. Hasseltii, Bl. Malacca to the Philippines.

D. pilosus, Roxb. Assam to Sumatra and Banka.

D. grandiflorus, Blanco. Penang, Banka, Philippines.

Hopea Pierrei, Hance. Cambodia, Singapore, and Borneo.

Shorea furfuracea, Miq. Malay Peninsula, Sumatra, Banka, Philippines.

S. gratissima, Dyer. Tenasserim to Singapore.

S. leprosula, Miq. Perak to Singapore, Sumatra, and Borneo.

The short distance to which these winged fruits or seeds drift is not confined to Dipterocarpeae, as will be illustrated by observations on plants of other orders.

Terminalia subspathulata, King (Combretaceae), is a lofty tree as much as Ico feet tall. It is endemic and rather local. The fruit is flat, thin, oblong rounded, one inch long and two inches across, with a single seed in the centre.

When detached by the wind it drifts along, rotating round its long axis and sometimes rising a little if the gust is strong. I found its limit of 
flight in a strong breeze was $3^{8}$ to 46 yards. These furthest flights were along a path, and on an open grass plot, where they may have drifted a little after reaching the ground, which could not happen and does not when they fall in jungle. Dropped from the verandah with Shorea leprosula fruit, they went a little further than that, and took longer to reach the ground. They flew most irregularly, sometimes in one direction, sometimes in another, when there was no wind.

Cumpassia Malaccensis (Leguminosae). Also a very lofty tree, often much over 100 feet. The thin one-seeded pod flies more slowly and rather further than those of Shorea. In an open space I found it reached 6I yards with a good wind. It is common all over the peninsula, and occurs in Borneo.

Sterculia scaphigera (Sterculiaceae). A very large tree, fruiting at 60 feet and upwards. The fruit consists of from one to five papery, green, boat-shaped carpels, 6 to 8 inches long, with a single seed at the base. The boat has a gibbous bend towards the base, at which point it is broadest. The boats when ripe become detached singly and drift along, the gibbous portion causing them to rotate briskly as they drift. In thick jungle I found the fruits $5 \circ$ yards from the main tree, none further.

Dyera costulata, Hook. fil. (Apocynaceae). This gigantic tree has a fruit consisting of a pair of wooden follicles which split along the upper edge, and release a large number of very thin, winged seeds about an inch across and elliptic. These seeds in a strong gale flew 40 yards only, though the tree is over Ico feet tall, and stands away from the forest on an open grass plot, so that it is fully exposed to the whole force of the wind. Dyera costulata inhabits the forests all over the peninsula, and occurs in Borneo also, and attains a height of over 200 feet.

Albizzia Moluccana, Bl. (Leguminosae). This is a large tree, 60 to 80 feet tall, introduced as a shade tree into the Malay Peninsula. It has thin, several-seeded pods ; when ripe they split, and one half carrying the seeds drifts away in the wind. As it is commonly planted in open ground the half pods drift along the ground very fairly far. It is very prolific, and grows with the greatest rapidity, but it does not move so fast if it is surrounded by dense forest, as I have seen it in long-abandoned estates on Gunong Pantai in Johor.

Spatholobus ferrugineus, Benth. (Leguminosae). A climber, often gigantic, very common in woods and also in the denser forests, where it climbs to a height of 80 or 90 feet or more. It only flowers when it reaches the light, and produces very large numbers of its thin-winged pods. A big plant, climbing to the top of the Terminalia subspathulata above mentioned and commonly fruiting there, shed its fruits to a distance of 60 feet. There is, however, a plant of this species in the jungle, 188 yards away from the big plant, which may be derived from 
it. The fruits are very light, and seem to drift much further than those of the Dipterocarpeae and Terminalia.

Ventilago leiocarpa, Benth. A climber to about $5 \circ$ or 60 feet on forest trees; has small linear-oblong fruits about 2 inches long and a quarter of an inch wide, with a seed at one end. The fruits are very light and thin, and fly about 40 yards, seldom further.

The following are the plants with winged fruits known to me from the Malay Peninsula :-

I. TREES :

Trigoniastrum. Small tree.

Sterculia, S. scaphigera, S. campanulata. Not very common. Distribution, Cambodia.

Tarrietia. Very large trees, fruits rather heavy.

Pentace. Several species.

Pteleocarpa. Medium tree, local. Fruits like those of Terminalia subspathulata. Edges of forests.

Dodonaea. Shrub; open sandy places and sea-shores ; widely spread.

Melannorhoea. Fruits with wings, widely spreading; common in dense forests. Those with no or abortive wings rare.

Parishia. Fruits winged like a Shorea; local. Big tree.

Dipterocarpeae. Allbut Retinodendron, Vatica (most), and Balanocarpus.

Kumpassia. Gigantic tree, common and widely spread.

Peltophorum. Medium-sized tree, abundant, open country only, never in forests.

Albizzia. Big tree, open country, introduced.

Terminalia subspathulata, King.

Homalium. Scarce, rarely fruiting.

Englehardtia. Tall tree, scarce.

II. CLIMBERS :

Securidaca. Very rare.

Ancistrocladus. Common, fruits like Shorea, abundant in open sandy places by the sea. Low scandent shrub.

Hiptage. Open country, usually rather a low climber.

Aspidopterys. Fruit as in Terminalia subspathulata; woods and riverbanks.

Cardiopteris. River-banks, rare.

Ventilago. Climber, forests.

Gouania. Low climber, open country.

Spatholobus, Kunstleria, Derris, Dalbergia (several species).

Mezoneurum. All edges of woods, open country, rarely in dense forest.

Combretums, Calycopteris and some Illigera, Sphenodesma. Open wood edges, and thickets.

Linostoma. Usually edges of forest. 


\section{Winged-fruit Plants in Insular Floras.}

Plants whose seeds or fruits are dispersed by the aid of wings are very rare in oceanic islands, about 2 per cent. of the species; and of these in some cases I am doubtful as to whether the plants reached the islands by the aid of the seed-wings. Notoriously absent are the Dipterocarpeae, wing-seeded A pocynaceae, and Bignoniaceae.

In Christmas Island I found only one, viz. Gyrocarpus, a sea-shore tree with fruit resembling that of a Dipterocarpus, and Berrya with smaller winged fruit, but both may possibly have been sea-drifted. In Fernando de Noronha were none, except possibly a Bignonia, the seeds of which were perhaps winged, but were not seen. There are none in Cocos Island nor the Admiralty Islands. Casuarina equisetifolia, which possesses thin winged seeds, is certainly sea-borne, as its distribution is that of other seaborne species, and it is exclusively a sea-sand plant, springing up along the edge of the sea-beaches. It occurs on many of the islands of the archipelago.

Of capsular plants with winged seeds, which drift from the split capsules when ripe, there are a number of trees in the Malay Peninsula and a few climbers. They include Cratoxylon, Gordonia, Archytea, Pterospermum, Ixonanthes, Triomma, Oroxylon, Dolichandrone, Duabanga, Norrisia, and Dyera ; and the climbers Alsomitra, Zanonia, Coptosapelta, Uncaria, Wightia, Dioscorea, Stemona, Nepenthes, and Aristolochia. The trees are usually small ones, except Dyera, and none are lofty plants like Dipterocarpeae. The climbers, too, are not usually large. The seeds being usually small, it is difficult to find them when fallen, so as to estimate the distance to which they can fly; but I judge from the appearance of seedlings near the trees that they fly but a few yards. Dyera has been described already. Uncaria seeds are so fine that they fly like dust-seeds when the pods open, and might be drifted in the wind to a very long distance. I do not know of any plant with winged seeds on oceanic islands.

\section{Plumed Seeds and Fruits.}

Fruits and seeds provided with silky plumes fly a good deal further than winged fruit, both in forest and still more so in open country. The flight of this class of fruit or seed is better known from observations in temperate countries, where the ground is more open and the fruit has a clear space to drift along; consequently these are more abundant than they are in a forest region, and indeed are much more easy to observe. In the Malay Peninsula we have very few indigenous terrestrial herbs with plumed seeds or fruits. The only ones inhabiting forests which I know of are Gynura sarmentosa, which is usually a low climber, and Blumea spectabilis. The former inhabits swampy spots in dense woods, but does often occur on the edges and on banks; the latter, a tall herb, on banks and 
open spaces in woods. In cultivated land are a number of introduced weeds, Compositae chiefly, which have plumed fruit; but many of these migrate more rapidly by attaching themselves to clothing (e. g. Ageratum conyzoides) than by the action of the wind. This is very marked where new country is being opened up by paths through forests, where these adhesive plumed Composites appear in a new clearing connected by a path with an old one long before the non-adhesive ones do. Indeed, of the Composite weeds common in this region the greater number are plumeless.

On sandy or muddy shores, where the country is treeless or nearly so, we have Pluchea Indica, and also Spinifex, the heads of which are rolled along the sandy shores. The Lalang grass Imperata cylindrica has plumed seeds which become detached by the wind and drift away; but the plant is only two or three feet tall usually, and I found in a fairly strong wind only flew on the level for about I6 yards. From hill-tops and such places it might fly further, but it seems never to migrate over a forest belt of about 30 yards thickness. If a clearing is made in forest Lalang does not appear unless through a wide open path, or when it is carried by man. Quite a narrow band of thick wood will often stop its movements completely.

Of jungle trees with plumed seed or fruit we have very few, and these are usually more abundant in open country and edges of woods: Vernonia arborea, a fairly tall tree, abundant in open cleared land but not at all a forest tree, Vallaris, and two or three Alstonias. The seeds of Alstonia scolaris, a very tall tree, I have seen drifting at the distance of a hundred yards and more from the parent tree. They perhaps drift much further even in forest, but it is very difficult to follow them in dense woods.

Clematis and Naravelia have plumed fruit. They are climbers on the edges of woods generally, and are not common. Of the Apocynaceae, besides the Alstonia and Vallaris mentioned above, there are a number of plume-seeded genera and species, of which a few inhabit the forests, climbing to the tops of the trees; such are Urceola and Parameria. The shrubs Strophanthus and small climbers Parsonsia, Wrightia, \&c., only occur in open country or edges of woods.

Parameria polyneura is a big forest climber ascending to 60 or 70 feet on the trees. It fruits heavily. The seeds drift in a good wind for 60 to 100 yards, slowly descending. If they fall on open ground such as a path or grass they drift along it still further. From a climber on a tree 60 feet tall in the Botanic Gardens, I find the furthest seed dropping at forty yards in a fair wind and drifting along the path for another 60 yards. Plants occur in the jungle at a distance of about 108 yards from this big plant, and are doubtless derived from it. As these plants fruit when comparatively young, and frequently occur along the edges of woods and such spots where the fallen seeds can drift along more open 
ground, these plants doubtless have a more rapid dispersal than the slowgrowing wing-fruited trees.

The most abundant Apocynaceae, however, are those with fleshy fruit, dispersed by birds and mammals, or the sea-borne Cerbera.

The Asclepiadeae have all plumed seed except Sarcolobus, a tidal river plant, the seed of which is adapted for dissemination by water. They are not very abundant in the peninsula, and fall into two classes - the slender climbers, like Tylophora, which occur on the edges of the rivers and over bushes by the sea, \&c., and are absent from high jungle and mountains, and the epiphytic species, some Hoyas and Dischidia. Some of the latter are almost confined to the upper branches of lofty trees; others like D. Rafflesiana generally occur in low trees about 30 feet high in the open country, especially near the sea, and again on mountain-tops, but not between. $D$. coccinea occurs on very lofty tree-tops in the low country, and on smaller trees on mountain-tops. I believe the seeds of $D$. Rafflesiana fly to a considerable distance, but it is difficult to be certain. I have seen young plants about 60 yards from a tree full of old plants, but I do not by any means think this is their limit.

The only epiphytic Gesneraceae, Aeschynanthus and Agalmyla, have small plumed seed. They are much more widely distributed than the terrestrial species, the plumeless seeds of which are distributed by rainwater.

\section{Plumed Seeds and Fruits in Insular Floras.}

These are much rarer than one would naturally expect. One could easily conceive of their being carried high up into the air by a gale and drifted away to a distant island, but as a matter of fact plants with this mode of dissemination form only about I per cent. of the vegetation. In Christmas Island is one Hoya, and Blumea spectabilis; in Fernando de Noronha one Gomphocarpus; in the Admiralty Islands one Hoya. In Juan Fernandez, out of II 8 plants there are one Bromelia and twenty Compositae which may bear plumed seed ; but of these fourteen are endemic species, of two genera, and may of course be all descendants of two species, very early inhabitants of the island; but I have no works here which state whether these fruits are plumed or no.

\section{POWDER-SEED.}

The very fine powder-like seed of many flowering plants and spores of Ferns, Lycopodiums, and the cellular Cryptogams are well adapted for wind-dispersal, and are often very widely disseminated. It is, however, impossible to follow them in their flight, so that one has to judge of the distance they can go by the appearance of young plants at a distance from 
the parent, and from their occurrence in remote islands. Among the flowering plants we have the Orchids, Apostasia, and several species of Newwiedia and Balanophora, all of which have very light seed which can be drifted away by the wind.

The distance of the flight of Orchid seeds is probably, occasionally at least, very considerable, but I have but little direct information on this. Some epiphytic species were put in a Ficus Benjamina in a very open position-Cymbidium, a new species, and C. Finlaysonianum, and an Agrostophyllum. They fruited, and seeds of $C$. Finlaysonianum flew southwards and grew on Arenga trees at a distance of 30 yards, Agrostophyllum 90 yards ; the other Cymbidium 60 yards, northwards. Dendrobium pandaneti, which I planted on a Sago palm at one end of the garden, was found on some other Sagos nearly a mile away; but I am not quite certain that the plants descended from the ones I first brought to the garden. The plant only grows on stems of Sagus, Pandamus, and Cocos. One curious thing about these epiphytic Orchids is, that the seed flying from a tree does not usually rest on the side of the tree facing the original plant, but on the further side, as if round the tree there was an eddy of wind which carried it there. I have seen the same thing in Psilotum complanatum, the spores of which must have flown from a plant in the plant-house, upwards and south-westwards, and lit on the trunk of a Date-palm 100 yards away. Very few of the numerous Orchids cultivated in the Botanic Gardens have, however, reproduced themselves on the garden trees.

Orchids are not at all common as a rule in small islands. There were none in Fernando de Noronha. In Christmas Island, ten species are recorded; three are endemic, two species of Phreatia a genus Indo-Malayan and Pacific, and a Saccolabium; of the others, Sarcochilus carinatifolia occurs also on Pulau Aur, a small island off the east coast of the Malay Peninsula. Dendrobium crumenatum ranges very widely over the Malay archipelago, and I have seen quite fresh, green-looking plants of it floating in the sea on the way to Christmas Island. The other Dendrobium is allied to a Javanese species. I have also found there a Javanese species of Thelasis. Of terrestrial Orchids there is a Corymbis allied to, though distinct from, $C$. veratrifolia, a plant of which hardly distinct forms occur from Africa to Java; a Zeuxine and Didymoplexis pallens, a saprophytic plant ranging from the Himalayas to Java. This plant has a rather special modification for wind-dispersal, after fertilization. It is self-fertilized and the pedicels of the fruit elongate so as to be actually longer than the stem, and elevate the capsule well above the rotten leaves and the low ferns among which it grows. Carysanthes, also a widely distributed Orchid, has the same modification.

As a rule terrestrial Orchids are more widely distributed than epiphytic ones, and saprophytic species are remarkably widely distributed. Con- 
sidering how lightly the wind blows in the dense forest at the level at which these plants fruit, it is curious to what a distance they seem to drift. They must often float upwards above the foliage of the lofty trees beneath which they grow. One noticeable fact is that while all terrestrial Orchids have their ripe capsules erect, those of epiphytic species are always pendulous, so that the seed of the former have a tendency to rise in the wind and the latter to descend. Cryptogams, especially epiphytic ones, are certainly very widely and quickly disseminated by their spores. Dr. Treub's well-known paper on the Flora of Krakatau illustrates this. He shows there that the first plants to reach an island after the whole flora has been destroyed are Algae, and these are followed by ferns, and later by phanerogams.

The same phenomenon is seen in the case of epiphytes, as well as on bare rocks, or barren clay banks, or any such places where at first there is no vegetation.

On trees in the Botanic Gardens, Singapore, I note that the first epiphytes to appear are Algae, which settle wherever the trickling of rainwater makes it possible for them to grow. On quite smooth-barked trees such as Betel-nuts, Areca, or Cocos, nothing further except lichens usually appears, unless there happens to be a notch in the bark, or a small portion of the base of a leaf-stalk remains, which forms a nidus for spores of mosses. The next plants which appear when the moss has grown into a small patch are usually ferns, and later Orchids; occasionally Orchids come before ferns. On smooth cylindric trunks the first lichens that appear are those of thin texture, e.g. Graphidea, Opegrapha, \&c.; later occasionally Parmelias and Collemas develop, and from these thicker lichens start mosses or hepatics.

The same order of appearance takes place on brickwork and bare clay banks, except that Orchids rarely appear, and often mosses do not come; phanerogams, however, always come later than the Algae. On trees after the Algae, mosses, ferns and Orchids (if any are in the neighbourhood); plants whose seeds are disseminated by birds come next.

\section{Powder-SEed Plants in OCEanic Islands.}

The proportion of powder-seed plants in oceanic islands is usually very large, even if we exclude the cellular plants; but oceanic islands are apt to be dry in the early stages of their afforestation, so that many of this group cannot thrive. Fernando de Noronha possessed no Orchid, only one fern, and very few mosses or hepatics. These plants, however, were not very abundant on the adjacent mainland, which was somewhat dry, and the island itself was in most parts unsuited for the growth of ferns and mosses. 
Coral atolls, like Cocos Island, are also deficient, but with other islands it is different.

In Krakatau, after the eruption in 1886 , Dr. Treub found that out of 26 plants I I belonged to this group; Penzig, revisiting it in I 896 , found 62 plants, of which 16 are powder-seed plants. In Christmas Islands out of I 70 I found 33. South Trinidad out of II has 4; the Admiralty Islands out of 118 have $4 \mathrm{I}$; Kerguelen out of 27 has 6 ferns and lycopodiums, but it is also accredited with 154 mosses and 26 hepatics; St. Paul and Amsterdam Islands have i9 powder-seed plants (exclusive of cellular cryptogams) out of 33 plants.

These facts are, I think, sufficient to settle to a considerable extent the part played by the wind in seed-dispersal ; of the three classes of fruit and seed modified for wind-dispersal, that of winged seed and fruit is the slowest. The species migrate very slowly and are, usually at least, unable to cross any large tract of sea by this means alone. Plumed seeds and fruits, though easily and probably quickly disseminated over open country, for which they are most suited, are liable to be stopped in their migrations by dense forests. They can, at least occasionally, cross successfully large areas of sea.

Powder-seed, on the other hand, has the most rapid transit probably of any form of seed, and is most widely diffused.

HENRY N. RIDLEY. 


\section{$2 \mathrm{BHL}$ Biodiversity Heritage Library}

Ridley, H. N. 1905. "On the dispersal of seeds by wind." Annals of botany 19, 351-363. https://doi.org/10.1093/oxfordjournals.aob.a089006.

View This Item Online: https://www.biodiversitylibrary.org/item/233541

DOI: https://doi.org/10.1093/oxfordjournals.aob.a089006

Permalink: https://www.biodiversitylibrary.org/partpdf/318804

\section{Holding Institution}

Smithsonian Libraries

\section{Sponsored by}

Biodiversity Heritage Library

\section{Copyright \& Reuse}

Copyright Status: Not in copyright. The BHL knows of no copyright restrictions on this item.

This document was created from content at the Biodiversity Heritage Library, the world's largest open access digital library for biodiversity literature and archives. Visit BHL at https://www.biodiversitylibrary.org. 